\title{
A Strategy Based on the Dispersive Liquid-Liquid Microextraction of Cadmium in Environmental Samples Prior to Its Determination by Flame Atomic Absorption Spectrometry
}

\author{
Volkan Numan Bulut ${ }^{\mathrm{a}}$, Zekeriyya Bahadir ${ }^{\mathrm{b}}$, Sule Ceylan ${ }^{\mathrm{c}}$, and Mustafa Soylak ${ }^{\mathrm{d}, *}$ \\ a Macka Vocational School, Karadeniz Technical University, Macka, Trabzon, Turkey \\ b Department of Chemistry, Giresun University, Giresun, Turkey \\ ${ }^{c}$ Faculty of Health Sciences, Department of Occupational Health and Safety, \\ Artvin Coruh University, Artvin, Turkey \\ ${ }^{\text {d }}$ Department of Chemistry, Faculty of Sciences, Erciyes University, Kayseri, Turkey
}

\section{INTRODUCTION}

Our environment is becoming ever more polluted by heavy metals due to advances in industry, rapid population growth, and urbanization. This leads to land, water, andsoil pollution, which in turn is negatively impacting living organisms (1). Within this context, identifying heavy metals in environmental samples has become one of the most important subject areas within analytical chemistry. One of the single most dangerous and toxic heavy metals is cadmium (Cd) (2). Sources of cadmium within our environment include cadmium-based paints, cigarette smoke, and plastic products (as an additive) (3). The by-products of these industrial activities pollute natural water sources and ultimately, cadmium enters the human body. Cigarette smoke enters the lungs, and then circulates into the bloodstream and throughout the rest of the body. Cadmium leads to serious damage of renal tissue and renal capillary vessels and is a cause of osteoporosis by damaging bone tissue (4-6). Cadmium furthermore is known to cause various other health problems such as stomach aches, vomiting, the breakage/decay of bones, reproductive issues, infertility, both nervous and immune system damage, mental health issues, and damage to the DNA, and cancer (especially of the lungs) $(7,8)$.

Corresponding autbor.

E-mail: soylak@erciyes.edu.tr

Fax: +90 3524374933

\section{ABSTRACT}

A simple method was developed by combining dispersive liquid-liquid microexraction (DLLME) and flame atomic absorption spectrometry (FAAS). For the pre-concentration of trace amounts of cadmium, a new complexation chelate of 2-[(4-phenylpiperazine-5-thioxo4,5-dihydro-1,3,4-oxadiazole-2yl)methyl]-5-methyl-4-[2-(1H-indol e-3-yl)ethyl]-2,4-dihydro-3H-1,2,4triazole-3-one (PPTOMDT) was used and mixed with the solvents of chloroform and methanol. The mixture of the extraction solutions was then directly injected into an aqueous solution containing $\mathrm{Cd}^{2+}$ ions. After centrifugation, the settled phase was diluted with $500 \mu \mathrm{L}$ of ethanol/ nitric acid and aspirated into the FAAS. The limit of detection (LOD) was found at $0.69 \mu \mathrm{g} \mathrm{L}^{-1}$ under optimum conditions. The relative standard deviation (RSD) for 15 replicates at a $3.75 \mu \mathrm{g} \mathrm{L}^{-1}$ $\mathrm{Cd}^{2+}$ concentration level was $3.21 \%$. The calibration plot was linear within the range of 2.5-15 $\mu \mathrm{g} \mathrm{L}^{-1}$ of $\mathrm{Cd}^{2+}$. After the analytical characteristics were determined, the CRM-TMDW-500 Drinking Water and CRM-SA-C Sandy Soil C, both certified reference materials, were analyzed in order to validate the method. The application of the DLLME method has been successfully tested for the determination of cadmium in solid and liquid samples. The recoveries of the spiked sample ranged between $92-96 \%$.
This means that being informed of cadmium concentrations in environmental samples is of utmost importance. The United States Environmental Protection Agency (EPA) has stated the maximum containment level of cadmium in drinking water to be $5.0 \mu \mathrm{g} \mathrm{L}^{-1}$ (9). Inductively coupled plasma mass spectrometry (ICP-MS) (10) and graphite furnace atomic absorption spectrometry (GFAAS) (11) are the two techniques used to determine cadmium. However, these techniques are rather expensive. Consequently, flame AAS (FAAS) is a preferred means of designating cadmium and is comparatively lower in cost, faster, and easy to use $(12,13)$.

However, the matrix is a challenge for all spectroscopic techniques (14). In order to resolve this problem, separation and enrichment-based methods are applied which aim to conveniently change the analyte by collecting it within a lower volume. To date, several enrichment methods have been developed and modified in combination with AAS. Among these, solid phase extraction (SPE) (15), co-precipitation (16), and cloud point extraction (17) are commonly used. But, these methods require the use of a significant amount of chemicals and are very time-consuming, the solvents are going to waste and release secondary waste (from excess quantities) into the environment.

In recent years, a shift has started towards microextraction 
methods that lower their consumption of organic solvents to an utmost minimum, simplify the steps involved in preparing the samples, have a high rate of evaporation, and are convenient for automation (18). Liquid-phase microextraction (LPME) (19), single-drop microextraction (SDME) (20), solid phase microextraction (21), and dispersive liquid-liquid microextraction (DLLME) can be included within these methods. Of these extraction procedures, DLLME is an especially simple and fast method and was first developed in 2006 by Rezaee and his team in order to determine organic types (22). As of late, its use has been expanded to also determine inorganic types (23).

DLLME is a solvent-based extraction method that has been modified by shrinking the extraction phase rates. When solvents are of significantly heavier water and non-mixed with water such as chlorobenzene, carbon tetrachloride and tetrachloroethylene are used as an extraction solvent, polar solvents mixed with water such as acetone, ethanol, $\mathrm{MeOH}$, and ACAN are used as diffusion solvents (24). In this method, both a dispersive liquid as well as an extraction liquid mixed with water are rapidly poured into the solvent. This produces a cloudy solvent in which the analyte ions become enriched within the extraction solvent (25). This method's simplicity, efficiency in terms of time and cost, low sample volume, and high preconcentration factor are among the most important advantages diffusion-based liquidliquid microextraction carries (26).

In this study, DLLME has been refined to accurately determine cadmium ions in solid and aqueous environmental samples. This approach is reported for the very first time and uses a 2-[(4-phenylpiperazine-5-thioxo-4,5-dihydro1,3,4-oxadiazole-2-yl)methyl]-5-met hyl-4-[2-(1H-indole-3-yl)ethyl]-2,4-
dihydro-3H-1,2,4-triazole-3-one (PPTOMDT) compound substance as a complexation agent in order to convert cadmium ions into an organic phase. All experimental parameters have been carefully optimized in order to obtain the highest possible recovery.

\section{EXPERIMENTAL}

\section{Instrumentation}

A PerkinElmer ${ }^{\circledR}$ AAnalyst $^{\mathrm{TM}} 400$ flame atomic absorption spectrometer, equipped with deuterium background correction, was used for the experiments (PerkinElmer, Inc., Shelton, CT, USA). A cadmium hollow-cathode lamp was used. The air-acetylene flame flow rate was set between 2.5 and $17 \mathrm{~L} \mathrm{~min}^{-1}$ for the conventional working parameters. The instrumental operating parameters are listed in Table I.

The absorption spectra of the synthesized reagent were read using a Specord 210 Plus model spectrophotometer (Analytik Jena AG, Jena, Germany). A Merck-Millipore ${ }^{\circledR}$ Direct-Q ${ }^{\circledR} 8 \mathrm{UV}$ system was used to obtain ultrapure water (Merck, Germany). The $\mathrm{pH}$ values were measured with a Hanna 211 pH meter (Sigma-Aldrich Chemie GmbH, Germany). Digestion of the samples was performed using a Milestones Ethos D (Milestore Inc., Italy) with a closed vessel microwave system. A Sigma 3-16P model centrifuge (Sigma Laborzentrifugen GmbH, Germany) was used to form the sediment phase.

TABLE I

FAAS Instrumental Operating Conditions for Cadmium

\begin{tabular}{ll} 
Element & $\mathrm{Cd}$ \\
Wavelength & $228.8 \mathrm{~nm}$ \\
Slit Width & $1.5 \mathrm{~nm}$ \\
Lamp Current & $6 \mathrm{~mA}$ \\
\hline
\end{tabular}

\section{Chemicals and Solutions}

In order to prepare each of the solutions for the experiments, ultrapure water was used. For cadmium, stock solutions were prepared daily from a $1000-\mathrm{mg} \mathrm{L}^{-1}$ standard cadmium solution (Merck, Darmstadt, Germany). Acetic acid/sodium acetate buffer (0.1 $\left.\mathrm{mol} \mathrm{L}^{-1}, \mathrm{pH} 6.5\right)$ was used for $\mathrm{pH}$ adjustment. The other chemicals used include carbon tetrachloride, chloroform, dichloromethane, and carbon disulphide (each as extraction solvents) as well as ethanol, methanol, acetone, and acetonitrile as a disperser solvent, all obtained from Merck, Germany. The PPTOMDT compound was synthesized in accordance with the scientific literature at Karadeniz Technical University's Organic Chemistry Research Laboratory (27). The chelating agent, $0.2 \mathrm{~g} /$ $50 \mathrm{~mL}$ PPTOMDT solution in dimethyl sulfoxide/methanol (1:4), was prepared and then stored in a dark bottle.

The steam, sea, and tap water samples, collected from the Turkish province of Trabzon, were kept in polytetrafluoro-ethylene (PTFE) containers. In order to the block metallic ions from breaking down, the water samples were acidified with nitric acid before analysis. The liquid samples were stored in the dark at $4^{\circ} \mathrm{C}$ after being filtered with a $0.45 \mu \mathrm{m}$ pore-size membrane. The certified reference materials CRM-SA-C Sandy Soil and CRMTMDW-500 Drinking Water (HighPurity Standard Inc., Charleston, SC, USA) were used for DLLME method validation.

\section{Procedure}

An amount of $20 \mathrm{~mL}$ of a solution containing $3.75 \mu \mathrm{g} \mathrm{L}^{-1}$ of cadmium was stored in a plastic tube, calibrating its $\mathrm{pH}$ to 6.5 . Then, a mixture of $1000 \mu \mathrm{L}$ of methanol, $250 \mu \mathrm{L}$ of chloroform, and $0.5 \mathrm{mg}$ of PPTOMDT (\% $0.4 \mathrm{~m} / \mathrm{v}, 125 \mu \mathrm{L}$ ) was swiftly poured into the solu- 
tion, which formed a white cloudy solution. The solution was then centrifuged for 3 minutes at 3000 $\mathrm{rpm}$. By doing this, $\mathrm{Cd}^{2+}$ ions form a complex with the PPTOMDT compound upon entering a chloroform phase. After the decantation procedure, the obtained organic phase (to which $0.5 \mathrm{~mL}$ of $\mathrm{HNO}_{3}$ was added), the Cd concentration was determined by FAAS. The same DLLME method was also performed for the blank solutions. All experimental measurements were repeated three times.

\section{Preparation of the Samples}

Water samples in $20 \mathrm{~mL}$ amounts (stream, sea, spring, and tap) were collected from different parts of Trabzon, Turkey. The water samples were filtered through a 0.45 $\mu \mathrm{m}$ micropore membrane filter, an appropriate amount of acetate buffer was added to adjust the $\mathrm{pH}$ to 6.5 , and the DLLME procedure was applied. Commercial solid samples were purchased from a local market. With the aim of getting a cadmium content response, $0.45 \mathrm{~g}$ amounts of dried rice, noodles, cracked wheat, black tea, ground coffee, tobacco leaves, and cigarettes as well as a plastic toy weighing $0.20 \mathrm{~g}$ were stored by weight in sensitive Teflon ${ }^{\circledR}$ containers. Then $8.0 \mathrm{~mL}$ of concentrated nitric acid as well as $2.0 \mathrm{~mL}$ of $\mathrm{H}_{2} \mathrm{O}_{2}$ were added to break down each of the samples. Digestion was performed using a microwave system with a maximum pressure of 46 bar, maximum temperature of 300 ${ }^{\circ} \mathrm{C}$, and $650 \mathrm{~W}$ of electric power. Twenty minutes were allowed for cooling time. After the digestion process, the solutions were evaporated to near dryness. The remnants were filtered through blue filter paper and the samples diluted to 25 $\mathrm{mL}$ (stock solutions) with ultra-pure water for each solid sample. The stock solutions were diluted twofold for the plastic toy and four-fold for the remaining solid samples before analysis. The diluted samples were then analyzed using the proposed procedure as mentioned in the "Procedure" section.

\section{Preparation of CRMs}

In order to confirm the accuracy of the developed method, CRM-SAC Sandy Soil C and CRM TMDW500 Drinking Water were used. Portions $(0.10 \mathrm{~g})$ of CRM-SA-C Sandy Soil C were transferred into a Teflon vessels, and a mixture of $3.5 \mathrm{~mL}$ of $\mathrm{HNO}_{3}, 3.5 \mathrm{~mL}$ of $\mathrm{HCl}$, $1.0 \mathrm{~mL}$ of $\mathrm{HF}$, and $1.0 \mathrm{~mL}$ of $\mathrm{H}_{2} \mathrm{O}_{2}$ was added. After digestion, the solutions were heated to near dryness. Then, the solutions were cooled, diluted to $20 \mathrm{~mL}$ volume with deionized water in a calibrated flask, and the $\mathrm{pH}$ adjusted to 6.5 . Then, the obtained solutions were analyzed following the experimental procedure listed above. This procedure was also used to analyze the drinking water reference samples.

\section{RESULTS AND DISCUSSION}

Several parameters were examined in terms of what affects the cadmium ion recovery values. In order to obtain a high extraction recovery, the main analytical parameters affecting the complex formation between the PPTMODT and the cadmium are summarized below. After each of the values was optimized, a calibration graph for the method was created and applied successfully to the liquid and the solid samples.

\section{Characterization of the Complex}

The influence of the $\mathrm{Cd}^{2+}$ ions on the spectroscopic properties of the complex formed by the PPTMODT was also studied. First, a $6.0 \times 10^{-5} \mathrm{~mol} \mathrm{~L}^{-1}$ solution was prepared in order to dissolve the PPTMODT compound in methanoldimethyl sulfoxide (24.0/1.0 mL). Then, $6.0 \times 10^{-4} \mathrm{~mol} \mathrm{~L}^{-1}$ was calibrated for the cadmium ion solution. A total volume of $4 \mathrm{~mL}$ was mixed together by using $2.0 \mathrm{~mL}$ from each of the two prepared solutions. For a $4.0-\mathrm{mL}$ mixture containing $10 \mathrm{~mol} \mathrm{~L}^{-1}$ equivalents of the metal, the absorbance was measured using a $1 \mathrm{~cm}$ long absorption cell in the Specord 210 Plus model spectrophotometer (Analytik Jena AG, Jena, Germany). $\mathrm{Cd}^{2+}$ ions found in the PPTMODT compound are shown in Figure 1. An absorbance value decrease between 250 and $350 \mathrm{~nm}$ in terms of the presence of metal in the compound was discovered.

The mole ratio method was applied for the determination of the stoichiometric ratios of PPTOMDT with $\mathrm{Cd}^{2+}$ (28). Figure $1 \mathrm{~b}$ shows the molar-ratio plot for $\mathrm{Cd}^{2+}$. The absorption decrease was observed at $270 \mathrm{~nm}$ with an increase in the $\mathrm{Cd}^{2+}$ ion concentration. $\mathrm{A}_{\mathrm{o}}$ and $\mathrm{A}$ are the absorbance of free ligand and absorbance of the solution involving $\mathrm{Cd}^{2+}$ cation, respectively. The inflection point was 0.5 $\left(\left[\mathrm{Cd}^{2+}\right] /[\mathrm{L}]\right)$. It can thus be concluded that PPTOMDT formed a stable 1:2 (M:L) complex with $\mathrm{Cd}^{2+}$.

\section{Effect of pH}

The $\mathrm{pH}$ plays a substantial role on the formation of the metal chelate and its subsequent extraction $(5,29)$. By increasing the $\mathrm{pH}$ of the solutions, different molecular forms of metallic species with neutral, anionic, or cationic character are formed. These hydrolysis products formed in the solution help to select the optimum $\mathrm{pH}$ and/or suitable $\mathrm{pH}$ working range (30). The influences of $\mathrm{pH}$ on the extraction of cadmium from both the water as well as the solid samples were studied within the 2.0-10.0 range using phosphate, acetate, and ammonium chloride as the buffer solutions. Figure 2 shows the effect of $\mathrm{pH}$ on the extraction of $\mathrm{Cd}^{2+}$. The sharp increase in the recovery values of the cadmium ion in the range of $\mathrm{pH}$ 


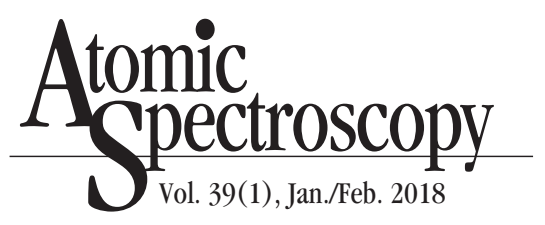

2 to 5 indicates that increasing the $\mathrm{pH}$ has a high effect on the enrichment method. The extraction efficiency maximum $\mathrm{pH}$ is 6-7 (92\%). Interactions between the positively charged metal ions and the ligand will increase with an increase in $\mathrm{pH}$. Because the relevant functional groups are completely deproteinized, the negative charge density on the ligand surface increases and thus the recovery efficiency of the metal ions increases (Figure 2). The metal-ligand interaction is probably less efficient at low $\mathrm{pH}$ values owing to proton competition with cadmium. Therefore, $\mathrm{pH} 6.5$ was selected for further study.

\section{Influence of the Amount of PPTOMDT}

The effect of the amount of PPTOMDT $(0.2 \mathrm{~g} / 50 \mathrm{~mL})$ on the preconcentrated cadmium was studied using various volumes of the reagent ranging from 50.0 to $175.0 \mu \mathrm{L}$. The results are shown in Figure 3. The extraction efficiency was stable when the PPTOMDT concentration was higher than 0.4 mg $(100 \mu \mathrm{L})$, indicating complete complexation. Thus, the amount of $0.5 \mathrm{mg}(125 \mu \mathrm{L})$ PPTOMDT was selected as the best choice for subsequent experiments.

\section{Effect of Type and Volume of the Disperser Solvent}

The selection of an appropriate disperser phase is crucial in DLLME. The selection of the disperser solvent is based on the miscibility of the solvent in both

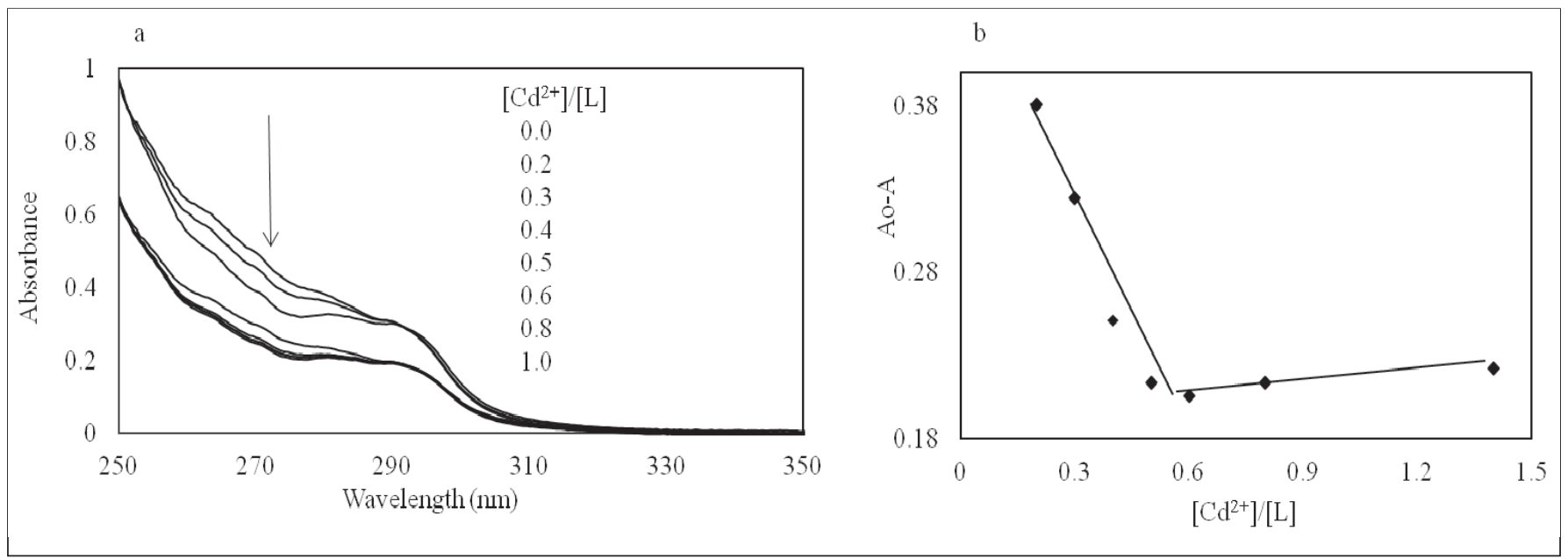

Fig. 1 ( $a$ and b). Absorption spectra of the PPTOMDT (a) and its complex stoichiometry with Cd ${ }^{2+}$, (b), Insets: Measurements were obtained at $270 \mathrm{~nm}$.

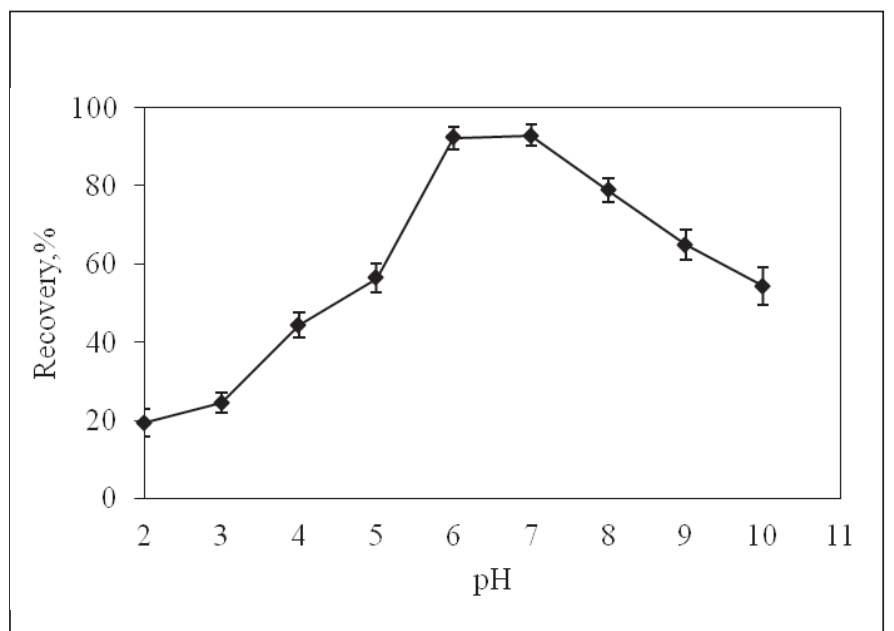

Fig. 2. The effect of $\mathrm{pH}$ on the preconcentration of cadmium using DLLME. Amount of chelating agent: $125 \mu L, 0.4 \%(w / v)$; sample volume: $20.0 \mathrm{~mL}\left(3.75 \mu \mathrm{g} \mathrm{L}^{-1} \mathrm{Cd}^{2+}\right)$; volume of $\mathrm{CHCl}_{3}$ : $250 \mu L$; volume of methanol: $1000 \mu L ;(n=3)$.

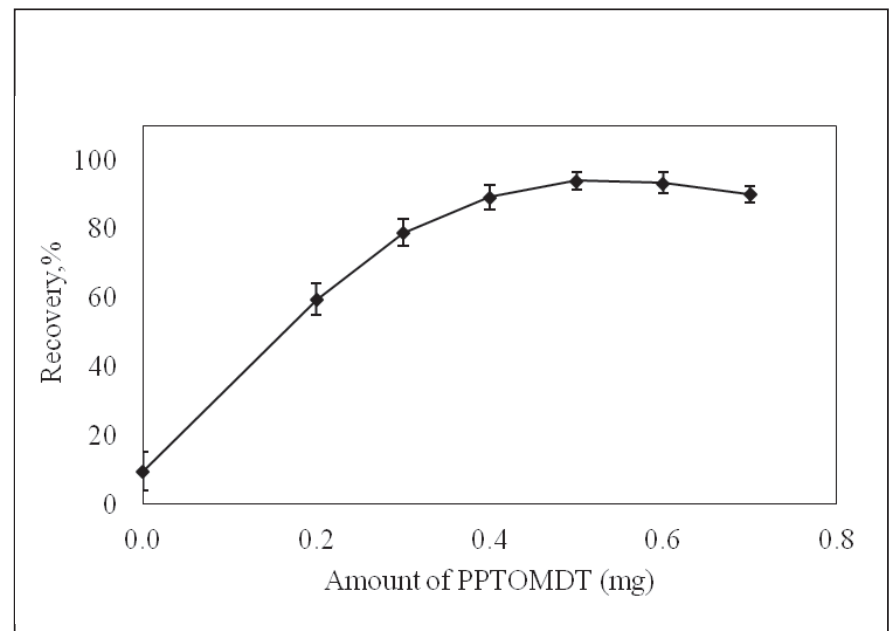

Fig. 3. Effect of amount of the PPTOMDT: Sample volume: $20.0 \mathrm{~mL}$ (3.75 $\left.\mu \mathrm{g} \mathrm{L}^{-1} \mathrm{Cd}^{2+}\right)$; $\mathrm{pH}$ : 6.5; methanol: $1000 \mu \mathrm{L},(n=3)$. 
the aqueous phase (sample solution) and the extraction solvent. For this purpose, different solvents were tested, including methanol, acetonitrile acetone, ethanol, and tetrahydrofuran. A series of sample solutions were studied using 1000 $\mu \mathrm{L}$ of each disperser solvent containing $250 \mu \mathrm{L}$ of chloroform $\left(\mathrm{CHCl}_{3}\right)$. The maximum extraction recovery was obtained using methanol (Figure 4a).

The disperser solvent volume can directly affect both the formation of the extraction efficiency and the degree of the dispersion of the extraction solvent in the aqueous phase. For this purpose, the effects of methanol were investigated in the range of $200-2000 \mu \mathrm{L}$ at the constant volume of chloroform (extraction solvent). The results showed that the cloudy suspension of droplets did not form well at lower volumes of methanol, resulting in a decrease in extraction efficiency. The extraction efficiency increased slightly upon increasing the volume of methanol from 200 to $1200 \mu \mathrm{L}$ (Figure 4b). It is clear that by increasing the volume of methanol, the solubility of the complex in water increased. The amount of $1000 \mu \mathrm{L}$ of methanol $(93.5 \% \pm 2.5)$ was thus employed to extract cadmium from the aqueous samples.

\section{Effect of Type and Amount of Extraction Solvent}

The volume and type of extraction solvent are important to the DLLME process. The extraction solvent should have a higher density than of water, an extraction capability for compounds of interest, and low solubility in water. The effects of certain solvents including carbon tetrachloride, chloroform, carbon disulfide, and dichloromethane were tested and examined using the $20-\mathrm{mL}$ cadmium solution with a $3.75 \mu \mathrm{g} \mathrm{L} \mathrm{L}^{-1}$ concentration. The results are provided in Figure 5a. Chloroform was found to provide a higher extraction efficiency.

The influence of the extraction solvent volume was investigated in the $100-400 \mu \mathrm{L}$ range. The extraction efficiency reached from $61 \%$ to $96 \%$ with an increase in volume of chloroform from 100 to $200 \mu \mathrm{L}$. Consequently, in subsequent stud- ies, $250 \mu \mathrm{L}$ chloroform was chosen to extract the cadmium from the aqueous samples (Figure 5b).

\section{Volume of Sample Solution}

The volume of the sample solution is another important factor in obtaining a high enrichment factor from the DLLME-based preconcentration. The effects of the sample volume on the cadmium recovery values were investigated while keeping other conditions constant. For this purpose, at optimum conditions, $0.075 \mu \mathrm{g}$ of cadmium was extracted at the range between 10.0 and $50.0 \mathrm{~mL}$. The extraction efficiency was observed to be constant up to $20.0 \mathrm{~mL}$. Then, by increasing the volume of the sample from $20.0 \mathrm{~mL}$ to $50 \mathrm{~mL}$, the extraction efficiency decreased. Therefore, $20.0 \mathrm{~mL}(96.7 \% \pm 2.6)$ was used as the optimum sample volume. During the analysis of both the model solution and the real water samples, the final sample volume was $0.5 \mathrm{~mL}$. Since the analyte was concentrated 40 times (from $20.0 \mathrm{~mL}$ to $0.5 \mathrm{~mL}$ ), the enrichment factor was 40 .

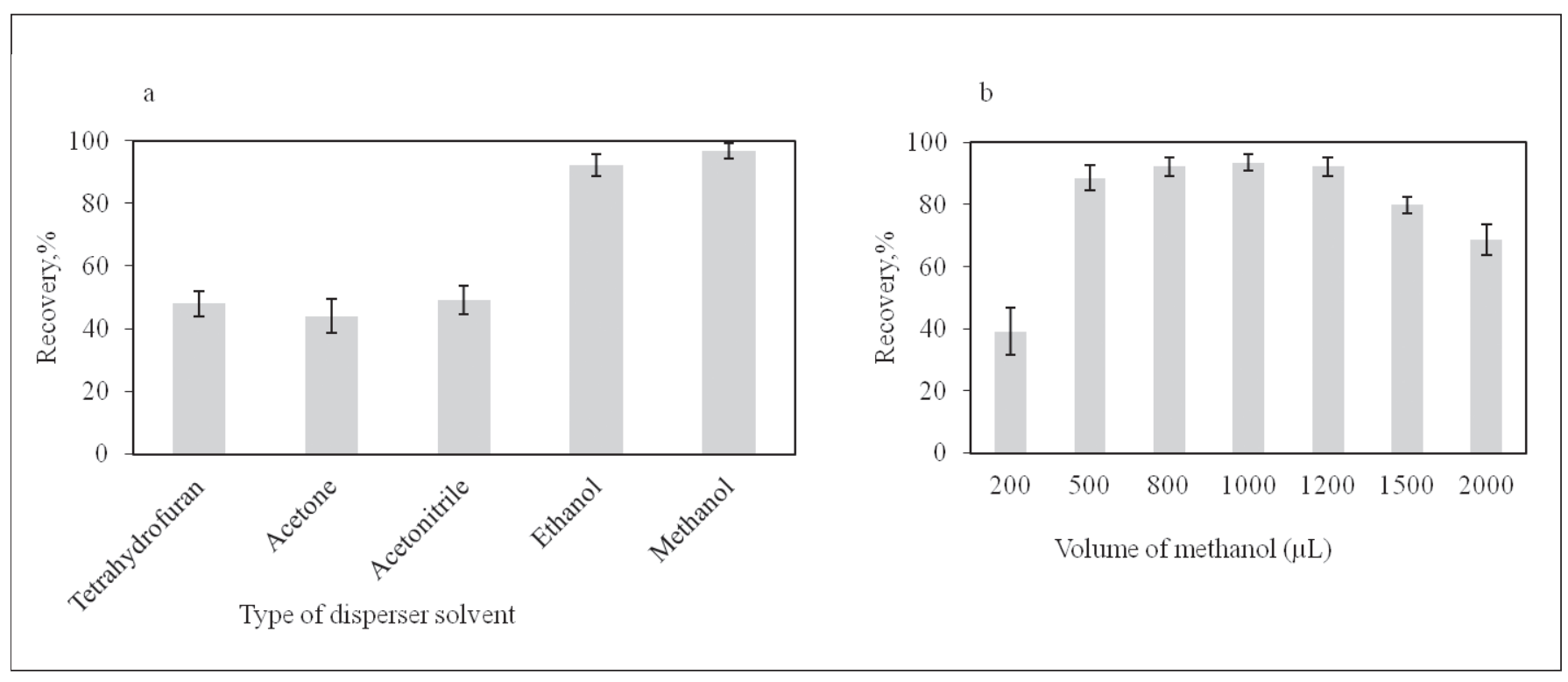

Fig. 4 ( $\left(a\right.$ and $b$ ). The effect of type of disperser solvent (a) and volume of methanol (b): Sample volume: $20.0 \mathrm{~mL}\left(3.75 \mu \mathrm{g} \mathrm{L}^{-1}\right.$ $\left.C d^{2+}\right)$; pH: 6.5; amount of chelating agent: $125 \mu \mathrm{L}, 0.4 \%(w / v)$; volume of methanol: $1000 \mu L,(n=3)$. 


\section{Atomic Apectroscopy \\ Vol. 39(1), Jan./Feb. 2018}

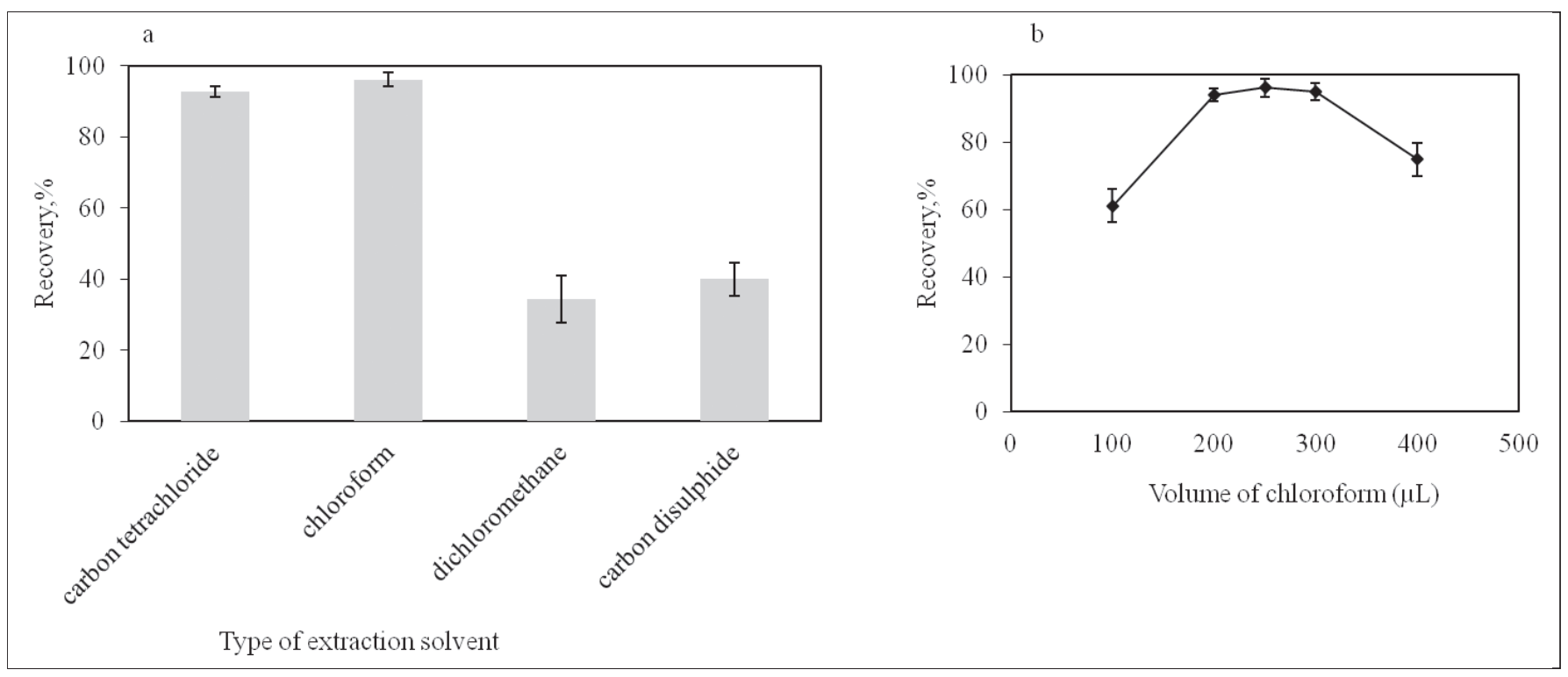

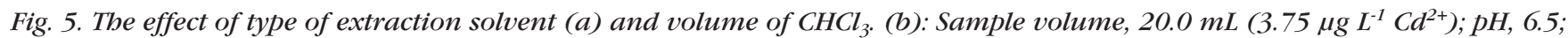
amount of chelating agent: $125 \mu \mathrm{L}, 0.4 \%(w / v)$; volume of methanol: $1000 \mu \mathrm{L},(n=3)$.

\section{Effect of Foreign Ions}

Environmental samples usually have a complex matrix system. These matrix systems in the sample may affect the recovery of the analyte. Therefore, the effect of foreign ions was examined by using the model solutions containing a fixed quantity of $\mathrm{Cd}^{2+}$ ion and different interfering ions as listed in Table II. In these experiments, 20.0-mL solutions containing $0.075 \mu \mathrm{g}$ of cadmium as well as various amounts of interfering ions were treated according to the recommended procedure. As shown in Table II, there is no important interference from the foreign ions in the environmental samples for the determination of cadmium.

\section{Analytical Performance}

The proposed method was evaluated under the selected experimental conditions by controlling the calibration range, limit of detection (LOD), and precision. Linearity was observed over the range of 2.5-15.0 $\mu \mathrm{g} \mathrm{L}^{-1}$ with a correlation coefficient $\left(\mathrm{R}^{2}\right)$ of 0.9962 . The limit of detection (LOD) is determined by utilizing both the measured limit of the blank (LOB) and the test replicates of a sample known to contain a low concentration of the analyte (Eq. (1)) (31). The mean and Standard deviation (SD) of the low concentration sample is then calculated according to the following equations:
Eq. 1 $\mathrm{LOD}=\mathrm{LOB}+1.645$ (SD low concentration sample)

The LOB is estimated by measuring replicates of a blank sample and calculating the mean result and the SD (see Eq. 2).

TABLE II

Effect of Some Foreign Ions on the Recovery of $3.75 \mu \mathrm{L} \mathrm{L}^{-1} \mathrm{Cd}^{2+}(\mathrm{n}=3)$

\begin{tabular}{lccc}
\hline Ion & Added as & Concentration $\left(\mathrm{mg} \mathrm{L}^{-1}\right)$ & Recovery (\%) \\
\hline $\mathrm{Na}^{+}$ & $\mathrm{NaCl}$ & 15000 & $94 \pm 3$ \\
$\mathrm{~K}^{+}$ & $\mathrm{KCl}$ & 5000 & $93 \pm 2$ \\
$\mathrm{Ca}^{2+}$ & $\mathrm{CaCl}_{2}$ & 500 & $93 \pm 2$ \\
$\mathrm{Mg}^{2+}$ & $\mathrm{Mg}\left(\mathrm{NO}_{3}\right)_{2}$ & 300 & $94 \pm 2$ \\
$\mathrm{Ba}^{2-}$ & $\mathrm{BaCl}_{2}$ & 20 & $95 \pm 2$ \\
$\mathrm{Mn}^{2+}$ & $\mathrm{Mn}\left(\mathrm{NO}_{3}\right)_{2}$ & 10 & $95 \pm 3$ \\
$\mathrm{Zn}^{2+}$ & $\mathrm{Zn}\left(\mathrm{NO}_{3}\right)_{2}$ & 10 & $94 \pm 1$ \\
$\mathrm{Al}^{3+}$ & $\mathrm{Al}\left(\mathrm{NO}_{3}\right)_{3}$ & 15 & $96 \pm 2$ \\
$\mathrm{~Pb}^{2+}$ & $\mathrm{Pb}\left(\mathrm{NO}_{3}\right)_{2}$ & 10 & $95 \pm 2$ \\
$\mathrm{Cu}^{2+}$ & $\mathrm{Cu}\left(\mathrm{NO}_{3}\right)_{2}$ & 5 & $95 \pm 2$ \\
$\mathrm{Fe}^{3+}$ & $\mathrm{Fe}\left(\mathrm{NO}_{3}\right)_{3}$ & 15 & $94 \pm 2$ \\
$\mathrm{Ni}^{2+}$ & $\mathrm{Ni}^{2+}\left(\mathrm{NO}_{3}\right)_{2}$ & 10 & $95 \pm 3$ \\
$\mathrm{Cr}^{3+}$ & $\mathrm{Cr}^{2+}\left(\mathrm{NO}_{3}\right)_{2}$ & 10 & $94 \pm 2$ \\
$\mathrm{SO}_{4}^{2-}$ & $\mathrm{Na}_{2} \mathrm{SO}_{4}$ & 750 & $95 \pm 2$ \\
$\mathrm{HCO}_{3}^{-}$ & $\mathrm{NaHCO}_{3}$ & 1500 & $95 \pm 2$ \\
$\mathrm{PO}_{4}^{3-}$ & $\mathrm{Na}_{3} \mathrm{PO}_{4}$ & 50 & $94 \pm 3$ \\
\hline
\end{tabular}


Eq. 2

$\mathrm{LOB}=$ mean $($ blank $)+1.64(\mathrm{SD}$ blank)

The enrichment factor (EF) was 40 times, and calculated as the ratio between the volume of the aqueous phase $(20 \mathrm{~mL})$ and the final volume $(500 \mu \mathrm{L})$. The relative standard deviation (RSD) for the analysis of 10 replicate measurements of a 20mL solution containing $3.75 \mu \mathrm{g} \mathrm{L}^{-1}$ $\mathrm{Cd}^{2+}$ was $3.21 \%$.

\section{Analysis of Environmental Samples}

To verify the accuracy of the proposed method, the cadmium concentrations were determined using the present method for CRMSA-C Sandy Soil C and CRM-TMDW500 Drinking Water after the appropriate dilution was made. As can be seen in Table III, recoveries were obtained between $95 \%$ and $96.3 \%$, respectively. The method was also applied for Cd determination in various water samples taken from the Turkish city of Trabzon.

TABLE III

Determination of Cadmium in Certified Reference Materials $(n=3)$

\begin{tabular}{lccc}
\hline Sample & Certified & Found & Recovery \\
\hline CRM-SA-C Sandy Soil C $^{\mathrm{a}}$ & $109 \pm 8.0 \mu \mathrm{g} \mathrm{g}^{-1}$ & $105 \pm 2.8 \mu \mathrm{g} \mathrm{g}^{-1}$ & $96.3 \pm 3.1 \%$ \\
CRM TMDW-500 Drinking Water & $10.0 \pm 0.1 \mu \mathrm{g} \mathrm{L}^{-1}$ & $9.5 \pm 0.3 \mu \mathrm{g} \mathrm{L}^{-1}$ & $95.0 \pm 2.6 \%$ \\
\hline
\end{tabular}

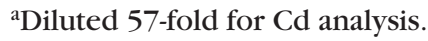

Stream and seawater samples were filtered using $0.45-\mu \mathrm{m}$ membrane filters, and the $\mathrm{pH}$ solutions were adjusted to 6.5. To show the applicability of the presented DLLM, the tap, stream, spring, and seawater as well as samples of burghul, noodles, rice, black tea, coffee, tobacco, cigarettes, and plastic toys were analyzed for their cadmium content. The recoveries of the spiked samples and the results obtained from the analysis of the environmental samples are presented in Tables IVa, IVb, and V.

\section{Comparison to Other Extraction} and Preconcentration Methods

A comparison of the proposed method with other reported extrac- tion and preconcentration methods for $\mathrm{Cd}^{2+}$ determination is given in Table VI (12, 32-37). The DLLME method has several advantages andincludes short extraction time, negligible consumption of extraction solvents, and simplicity. It can be observed that the detection limit obtained in this study is compatible with studies that use FAAS as the detection system $(35,36)$. The limits of detection are lower than that of the previously reported methods except for reference 36 and reference 37 . In addition, the DLLME technique is competitive in terms of sensitivity when compared with widely used sample preparation techniques, such as solid-phase extraction (SPE) and cloud point
TABLE IVa Determination of Cadmium in Spiked Samples $(\mathbf{n}=3)$

\begin{tabular}{lccc}
\hline Sample & Added $(\mu \mathrm{g})$ & Found $(\mu \mathrm{g})$ & Recovery $(\%)$ \\
\hline \multirow{2}{*}{ Tap water } & 0 & $<\mathrm{LOD}$ & - \\
& 0.075 & $0.071 \pm 0.001$ & $94.6 \pm 2.1$ \\
& 0.150 & $0.143 \pm 0.003$ & $95.3 \pm 2.2$ \\
Stream water & 0.075 & $0.070 \pm 0.001$ & $93.3 \pm 2.1$ \\
& 0.150 & $0.014 \pm 0.005$ & $93.3 \pm 3.1$ \\
Spring water & 0.075 & $0.079 \pm 0.002$ & $96.0 \pm 2.4$ \\
& 0.150 & $0.144 \pm 0.004$ & $96.0 \pm 3.1$ \\
Sea water & 0 & $<\mathrm{LOD}$ & - \\
& 0.075 & $0.070 \pm 0.003$ & $93.3 \pm 3.0$ \\
Burghul & 0.150 & $0.141 \pm 0.005$ & $94.0 \pm 3.1$ \\
& 0 & $<\mathrm{LOD}$ & - \\
& 0.075 & $0.070 \pm 0.002$ & $93.3 \pm 2.7$ \\
& 0.150 & $0.143 \pm 0.004$ & $95.3 \pm 2.4$ \\
Noodle & 0 & $<\mathrm{LOD}$ & - \\
& 0.075 & $0.069 \pm 0.001$ & $92.0 \pm 2.0$ \\
& 0.150 & $0.142 \pm 0.002$ & $94.6 \pm 2.2$ \\
\hline
\end{tabular}

TABLE IVb

Determination of Cadmium in Spiked Samples $(n=3)$

\begin{tabular}{|c|c|c|c|}
\hline Sample & Added $(\mu \mathrm{g})$ & Found $(\mu \mathrm{g})$ & Recovery (\%) \\
\hline \multirow[t]{3}{*}{ Rice } & 0 & $<$ LOD & - \\
\hline & 0.075 & $0.070 \pm 0.002$ & $93.3 \pm 2.6$ \\
\hline & 0.150 & $0.146 \pm 0.001$ & $97.3 \pm 2.5$ \\
\hline \multirow[t]{3}{*}{ Black tea } & 0 & $<$ LOD & - \\
\hline & 0.075 & $0.068 \pm 0.002$ & $90.6 \pm 2.1$ \\
\hline & 0.150 & $0.140 \pm 0.005$ & $93.3 \pm 3.0$ \\
\hline \multirow[t]{3}{*}{ Coffee } & 0 & $<$ LOD & - \\
\hline & 0.075 & $0.069 \pm 0.002$ & $92.0 \pm 3.0$ \\
\hline & 0.150 & $0.141 \pm 0.001$ & $94.0 \pm 2.0$ \\
\hline \multirow[t]{3}{*}{ Tobacco } & 0 & $0.093 \pm 0.003$ & - \\
\hline & 0.075 & $0.164 \pm 0.005$ & $94.6 \pm 2.2$ \\
\hline & 0.150 & $0.237 \pm 0.007$ & $96.0 \pm 2.4$ \\
\hline \multirow[t]{3}{*}{ Cigarette } & 0 & $0.079 \pm 0.003$ & - \\
\hline & 0.075 & $0.150 \pm 0.004$ & $94.6 \pm 2.1$ \\
\hline & 0.150 & $0.224 \pm 0.004$ & $96.6 \pm 2.3$ \\
\hline \multirow[t]{3}{*}{ Plastic toys } & 0 & $0.064 \pm 0.003$ & - \\
\hline & 0.075 & $0.136 \pm 0.003$ & $94.6 \pm 2.4$ \\
\hline & 0.150 & $0.209 \pm 0.003$ & $96.6 \pm 2.4$ \\
\hline
\end{tabular}


TABLE V

Results of Determination of Cadmium in Solid and Water Samples $(n=3)$

\begin{tabular}{llll}
\hline Solid Samples & $\mathrm{Cd}^{2+}\left(\mu \mathrm{g} \mathrm{g}^{-1}\right)$ & Water Samples & $\mathrm{Cd}^{2+}\left(\mu \mathrm{g} \mathrm{L}^{-1}\right)$ \\
\hline Burghul & $<\mathrm{LOD}$ & Tap water & $<\mathrm{LOD}$ \\
Noodle & $<$ LOD & Stream water & $<$ LOD \\
Rice & $<$ LOD & Spring water & $<$ LOD \\
Black tea & $<$ LOD & Seawater & $<\mathrm{LOD}$ \\
Coffee & $<$ LOD & & \\
Tobacco & $1.03 \pm 0.02$ & & \\
Cigarette & $0.88 \pm 0.03$ & & \\
Plastic toys & $0.80 \pm 0.03$ & & \\
\hline
\end{tabular}

TABLE VI

Comparison of DLLME with Other Methods for Determination of Cadmium

\begin{tabular}{|c|c|c|c|c|c|}
\hline Method & LOD & $\begin{array}{l}\mathrm{EF} / \mathrm{PF} \\
\left(\mu \mathrm{g} \mathrm{L}^{-1}\right)\end{array}$ & $\begin{array}{c}\text { Linear } \\
\text { Range }\left(\mu \mathrm{g} \mathrm{L}^{-1}\right)\end{array}$ & $\begin{array}{l}\text { Sample } \\
\text { Type }\end{array}$ & Ref. \\
\hline USAEME-FAAS & 0.91 & 15.3 & $10-600$ & $\begin{array}{l}\text { Tap, sea, river, } \\
\text { wastewater }\end{array}$ & $\begin{array}{l}12 \\
12\end{array}$ \\
\hline SPE-FAAS & 1.44 & 50 & 216-3000 & $\begin{array}{l}\text { Tap water, tea } \\
\text { leaves }\end{array}$ & 32 \\
\hline CPE-FAAS & 0.75 & $15.1-20.3$ & $32.5-500$ & Mineral, river, lake & 33 \\
\hline HFRLM-FAAS & 1.5 & 107 & $5-30$ & River water & 34 \\
\hline SPE-FAAS & 5.5 & - & $5-150$ & $\begin{array}{l}\text { Alcohol fuel } \\
\text { samples }\end{array}$ & 35 \\
\hline $\begin{array}{l}\text { USAE-SFODME- } \\
\text { FAAS }\end{array}$ & 0.66 & 81 & $10-450$ & $\begin{array}{l}\text { Tap, sea, river } \\
\text { water }\end{array}$ & 36 \\
\hline IL-UADMME-FAAS & 0.40 & 100 & $10-500$ & $\begin{array}{l}\text { Lake and wastewater,- } \\
\text { onion, tomato, green } \\
\text { chilli, peppermint, } \\
\text { hair samples }\end{array}$ & 37 \\
\hline DLLME-FAAS & 0.69 & 40 & $2.5-15$ & $\begin{array}{l}\text { Tap, stream, spring, } \mathrm{P} \\
\text { Spring, seawater; } \\
\text { burghul, noodle, } \\
\text { rice, black tea, coffee, } \\
\text { tobacco, cigarette, } \\
\text { plastic toy samples }\end{array}$ & $\begin{array}{l}\text { resent } \\
\text { Work }\end{array}$ \\
\hline
\end{tabular}

LOD: limit of detection.

EF: Enhancement factor.

PF: preconcentration factor.

USAEME: Ultrasound assisted emulsification microextraction.

CPE: Cloud point extraction.

HFRLM: Hollow fiber renewal liquid membrane extraction.

IL-UADMME: Ionic liquid-based ultrasound-assisted dual magnetic microextraction. USAE-SFODME : Ultrasound-assisted emulsification solidified floating organic drop microextraction.

\section{Atomic Apectroscopy \\ Vol. 39(1), Jan./Feb. 2018}

extraction (CPE). Also, the developed method has an advantage in that it can be applied to different types of samples compared with the other methods described in Table VI. However, the preconcentration factor of the proposed method is lower than that of the previously reported methods except for reference 12 and reference 33. Thus, the analytical characteristics of the recommended method could be a good cadmium detection alternative for analytical laboratories.

\section{CONCLUSION}

In this method, a dispersive liquid liquid microextraction (DLLME) method is presented for the preconcentration of cadmium in water and solid samples and FAAS-based analysis. The PPTMODT compound of 2-[(4-phenylpiperazine-5-thioxo4,5-dihydro-1,3,4-oxadiazole-2-yl) methyl]-5-methyl-4-[2-(1H-indole3-yl)ethyl]-2,4-dihydro-3H-1,2,4-triazole-3-on was successfully used for the first time in the determination of cadmium ions in environmental samples. A mixture comprised of $1000 \mu \mathrm{L}$ of methanol (dispersive solvent) and $250 \mu \mathrm{L}$ of chloroform (extraction solvent) was able to quantitatively extract cadmium ions. This method also has several merits which includes simplicity of operation, good repeatability, high recoveries, and low consumption of organic solvent. The measured analytical performance demonstrates that this method is a good alternative for the determination of $\mathrm{Cd}$ in both water and solid samples in the low $\mu \mathrm{g} \mathrm{L}^{-1}$ range with good accuracy and good reproducibility.

\section{ACKNOWLEDGMENT}

This work has been supported by the Scientific Research Projects of Karadeniz Technical University (Project no: 1223), Turkey.

Received June 30, 2017. 


\section{REFERENCES}

1. S. Khan, T.G. Kazi, and M. Soylak, Toxicol. Environ. Chem. 95, 1069 (2013).

2. V.A. Lemos, and L.A. Oliveira, Food Control 50, 901 (2015).

3. K. Karaboduk, E. Hasdemir, and M.L. Aksu, GU. J. Sci. 30, 215 (2017)

4. A. Duran, M. Tuzen, and M. Soylak, Atom. Spectrosc. 34, 99 (2013).

5. M. Chamsaz, A. Atarodi, M. Eftekhari, S. Asadpour, and A. Mina, J. Advanced Res. 4, 35 (2013).

6. B. Fagerberga, Y. Borné, L. Barregard, G. Sallsten, N. Forsgard, B. Hedblad, M. Persson, and G. Engström, Environ. Res. 152, 185 (2017).

7. M. Tuzen, and M. Soylak, Food Chem. 101, 1378 (2007).

8. I.I. Ozyigit, O.L. Uyanik, N.R. Sahin, I.E. Yalcin, and G. Demir, Pol. J. Environ. Stud. 26, 773 (2017).

9. D. Mendil, O.F. Unal, M. Tuzen, and M. Soylak, Food Chem. Toxicol. 48, 1383 (2010).

10. Y. Zhu, and K. Chiba, Talanta, 90 , 57 (2012)

11. D. J. Butcher, Appl. Spectrosc. Rev. 41, 15 (2006).

12. G. Khayatian, and M. Hassanpour, Anal. Bioanal. Chem. Res., 5, 11 (2018).

13. J. Abolhasani, and M. Behbahani, Environ. Monit. Assess. 187, 4176 (2015).

14. E. Zeini, J.A. Bidari, Y. Assadi, M.R.M. Hosseini, and M.R. Jamali, Anal. Chim. Acta 585, 305 (2007).

15. L. Elci, M. Soylak, and M. Dogan, Fresen. J. Anal. Chem. 342, 175 (1992).

16. S. Saracoglu, M. Soylak, and L. Elci, Trace Elem. Electroly. 18, 129 (2001).

17. G. Xiang, S. Wen, X. Wu, X. Jiang, L. He, and Y. Liu, Food Chem. 132, 532 (2012).

18. H.M. Al-Saidi, and A.A.A. Emara, J. Saudi Chem. Soc. 18, 745 (2014).
19. F. Pena-Pereira, I. Lavilla, and C. Bendicho, Anal. Chim. Acta 669, 1 (2010).

20. A. Jain, and K.K. Verma, Anal. Chim. Acta, 706, 37 (2011).

21. Z. Mester, and R. Sturgeon, Spectrochim. Acta 60B, 1243 (2005).

22. M. Rezaee, Y. Assadi, M.R.M. Hosseini, and E. Aghaee, J. Chromatogr. 1116A, 1 (2006).

23. E.M. Martinis, R.A. Olsina, J.C. Altamirano, and R.G. Wuilloud, Talanta 78, 857 (2009).

24. Z. Xiao-Huan, W. Qiu-Hua, Z. MeiYue, X. Guo-Hong, and W. Zhi, Chinese J. Anal. Chem. 37, 161 (2009).

25. M. Dehghani, M. Abadi, N. Ashraf, M. Chamsaz, and F. Shemirani, Talanta 99, 1 (2012).

26. M. Soylak, and Y.E. Unsal, Toxicol. Environ. Chem. 94, 1480 (2012).

27. S. Ceylan, H. Bayrak, A. Demirbas, S. Ulker, S.A. Karaoglu, and N. Demirbas, Russ. J. Bioorg. Chem+. 40, 314 (2014).

28. N. Kabay, Y. Baygu, Ü. Ocak, S. Gün, and Y. Gök, Sep. Sci. Technol. 50, 1002 (2015).

29. M. Soylak, L. Elci, and M. Dogan, Fresen. Environ. Bull. 5, 148 (1996)

30. K.J. Powell, P.L. Brown, R.H. Byrne, T. Gajda, G. Hefter, S. Sjöberg, and H. Wanner, Pure Appl. Chem. 83, 1163 (2011).

31. D.A. Armbruster, and T. Pry, Clin. Biochem. Rev. 29, 49 (2008).

32. O.M. Kalfa, O. Yalcınkaya, and A.R. Turker, J. Hazard. Mater. 66, 455 (2009).

33. E.L. Silva, and P.S. Roldan, J. Hazard. Mater. 161, 142 (2009).

34. R.M. Luciano, G.C. Bedendo, J.S. Carletto, and E. Carasek, J. Hazard. Mater. 177, 567 (2010).

35. V.N. Alves, R. Mosquetta, N.M.M. Coelho, J.N. Bianchin, K.C.D.P. Roux, E. Martendal, and E. Carasek, Talanta 80, 1133 (2010).

36. J.W. Zhang, Y.K. Wang, X. Du, X. Lei, J.J. Ma, and J.C. Li, J. Brazil. Chem. Soc. 22, 446 (2011).
37. S. Khan, T.G. Kazi, and M. Soylak, Spectrochim. Acta 123A, 194 (2014). 